Estudios Constitucionales, Año 8, No 1, 2010, pp. 169 - 200.

ISSN 0718-0195

Centro de Estudios Constitucionales de Chile Universidad de Talca

"La responsabilidad patrimonial del Estado legislador: un análisis a propósito de las garantías del contribuyente en el sistema chileno"

J. Ignacio Núñez Leiva

\title{
LA RESPONSABILIDAD \\ PATRIMONIAL DEL ESTADO LEGISLADOR: \\ UN ANÁLISIS A PROPÓSITO DE LAS GARANTÍAS DEL CONTRIBUYENTE EN EL SISTEMA CHILENO ${ }^{1}$
}

\author{
RESPONSIBILITY OF THE LEGISLATIVE GOVERNMENT: \\ A REVIEW ABOUT THE TAXPAYER'S CONSTITUTIONAL \\ RightS IN THE CHILEAN LEGAL SYSTEM
}

\author{
J. IgnaCio NúNEZ LeIVA ${ }^{2-3}$ \\ Profesor Universidad Alberto Hurtado. \\ jinunez@uc.cl
}

RESUMEN: El presente trabajo analiza, a propósito del sistema de garantías establecido para el contribuyente en la Constitución Política de la República de Chile, la figura de la responsabilidad patrimonial del Estado Legislador. Sugiere que el efecto irretroactivo asignado por la Carta Fundamental a las sentencias de inconstitucionalidad pronunciadas por el Tribunal Constitucional es un factor importante que podrí favorecer el instituto reparatorio por actos del legislador. Lo anterior en base a la experiencia española.

ABSTRACT: This article analyzes the topic of the responsibility of the government, as a legislative body, in the context of the constitutional rights of the taxpayers. Its suggest that the effect that Constitution have assigned to the judgments of the Constitutional Court, which declares unconstitutional the law, is an important factor that could help to repair issues caused by the state in its legislative function.

PalabRas Clave: Responsabilidad Estado Legislador. Responsabilidad del Estado. Garantías del contribuyente.

KEY WORDS: Responsibility of the legislative government. State liability. Taxpayer's constitutional Rights.

\footnotetext{
${ }^{1}$ Recibido el 4 de octubre de 2009 y aceptado el 13 de enero de 2010. Trabajo elaborado con el respaldo del sistema de Fondos Concursables de Investigación para académicos de la Facultad de Derecho de la Universidad Alberto Hurtado. Dicho concurso fue adjudicado al proyecto presentado por el autor en el año 2008.

${ }^{2}$ Abogado. Licenciado en Derecho por la Pontificia Universidad Católica de Chile. Diplomado en Derechos Humanos, Universidad Católica de Uruguay. Especialista en Constitucionalismo y Garantismo, Universidad de Castilla La Mancha, España. Magíster (c) en Derecho Público, Pontificia Universidad Católica de Chile. Doctorando en Derecho, Universidad de Castilla La Mancha, España Profesor de Derecho Constitucional en las Universidades: Alberto Hurtado, Andrés Bello y de las Américas.

${ }^{3}$ Se agradece la colaboración prestada a doña María Celeste Mora Escobar, profesora de la Facultad de Derecho de la Universidad Andrés Bello y a don Patricio Álvarez-Salamanca M., alumno de la Facultad de Derecho de la Universidad Alberto Hurtado, quien colaboró como ayudante en el marco del ya mencionado proyecto de investigación.
} 


\section{INTRODUCCIÓN}

La figura de la responsabilidad patrimonial del Estado Legislador ha hecho irrupción recientemente en el Derecho Público. Sin perjuicio de las alusiones que a ella se hacen en la doctrina administrativista de fines del siglo XVIII y comienzos del Siglo XX, el actualmente en curso, ha sido testigo privilegiado de su progresiva consolidación. La presente monografía tiene por objetivo reflexionar sobre este instituto jurídico en una de sus vertientes: la originada con motivo de la declaración de inconstitucionalidad de la ley.

Ello desde una perspectiva particular: la del contribuyente, y poniendo especial atención a un hecho que -a nuestro juicio- ha favorecido su proliferación: el desarrollo y establecimiento del efecto pro futuro para las sentencias estimativas de inconstitucionalidad. Para nosotros esta óptica encuentra su justificación en la reciente creación en el sistema chileno de un control de constitucionalidad represivo con efectos generales, capaz de expulsar un precepto legal del ordenamiento jurídico, por adolecer de un vicio de inconstitucionalidad, al cual la propia Carta Fundamental le asigna efectos irretroactivos.

En este contexto, nuestra hipótesis de trabajo es la siguiente: En jurisdicciones que cuentan con sistemas de justicia constitucional concentrados capaces de invalidar leyes vigentes mediante sentencias con efectos pro futuro, el contribuyente, en virtud del propio principio de supremacía constitucional y en atención al contenido de los derechos reconocidos por el propio sistema, goza de una garantía jurisdiccional de esos derechos constituida por la acción de responsabilidad patrimonial del Estado por actos del Legislador.

Para intentar confirmarla seguiremos el siguiente itinerario de trabajo. En primer lugar describiremos y clasificaremos las garantías del contribuyente en la Constitución chilena, luego nos referiremos al efecto de las sentencias de inconstitucionalidad pronunciadas por el Tribunal Constitucional chileno: inconstitucionalidad sin nulidad y su relación con la responsabilidad patrimonial del Estado Legislador, a continuación revisaremos y evaluaremos los argumentos que con mayor frecuencia se emplean para negar o afirmar la procedencia de la responsabilidad del Estado por actos del legislador, con posterioridad revisaremos algunos ejemplos de la aplicación de la figura en estudio como garantía del contribuyente y finalizaremos formulando algunas conclusiones.

\section{EXCURSO SOBRE LAS GARANTÍAS EXPLÍCITAS} DEL CONTRIBUYENTE EN LA CONSTITUCIÓN CHILENA

Como bien afirma Santiago Sastre, el término garantía es quizás uno de los más empleados por el lenguaje jurídico. En un sentido amplio, y distinguiéndolo 
debidamente de los objetos protegidos, podemos entender que con el concepto garantía se alude a los instrumentos o medios mediante los cuales el Derecho protege y tutela un bien o valor ${ }^{4} \mathrm{o}$ más específicamente a las técnicas de tutela de los Derechos Fundamentales. ${ }^{5}$

Sin lugar a dudas, la principal forma de garantía de un Derecho Fundamental es su positivación como tal. No en vano Zagrebelsky expresa -citando un pasaje de una sentencia de la Corte Suprema de los Estados Unidos ${ }^{6}$ - que el auténtico propósito de una declaración constitucional de derechos es sustraer ciertas materias de las controversias políticas. ${ }^{7}$ Por ello suele destacarse el carácter contramayoritario de los Derechos Fundamentales, pues el titular de un derecho de esta clase tiene la facultad de ejercerlo aun cuando la mayoría piense que hacerlo estaría mal, e incluso cuando la mayoría pudiese estar peor porque ese algo se haga. ${ }^{8}$

García Morillo, al referirse a los diversos mecanismos jurídicos de protección de los Derechos Fundamentales, distingue entre Garantías Abstractas y Concretas.

Según su esquema, son del primer tipo todas aquellas previsiones constitucionales que no están vinculadas a la vulneración real y concreta de un Derecho Fundamental, sino que constituyen condiciones o requisitos, de carácter general -pero no por eso menos obligatorios- para la actuación de los poderes públicos o que limitan dicha actuación. Se trata, en síntesis, de limitaciones al margen de actuación de los poderes públicos y, en particular, de los poderes Legislativo y Ejecutivo, y su objeto es evitar que normas de rango inferior a la Constitución, emanadas de alguno de los poderes citados, desarrollen los Derechos Fundamentales despojándoles del contenido y eficacia con que la Constitución pretende dotarles. Se las llama también garantías normativas; garantías cuyo destinatario no es el individuo, aunque éste puede utilizarlas o invocarlas si conviene a su derecho. ${ }^{9}$

Se cuentan, para el caso chileno, dentro de este elenco de garantías, entre otras: la Directa aplicabilidad de la Constitución y de los Derechos Fundamentales, las distintas Reservas legales establecidas a favor de Derechos Fundamentales, la salvaguardia del Contenido Esencial de los Derechos Fundamentales, ${ }^{10}$ el Recono-

\footnotetext{
${ }^{4}$ SASTRE (2000) p. 48.

${ }^{5}$ Ferrajoli (2008) p. 60.

${ }^{6}$ Se trata de la sentencia recaída sobre el caso "West Virginia Board of Education V. Barnette", específicamente de la opinión del juez Robert Jackson.

${ }^{7}$ ZaGRebelsky (2008) p. 26.

${ }^{8}$ Bordalí (2002) p. 63.

${ }^{9}$ García (1994) p. 27.

${ }^{10}$ García Morillo, comentando la Constitución española de 1978, atribuye el origen de la protección del Núcleo Esencial de los derechos al artículo 19.2 de la Ley Fundamental de Bonn. Norma que ha motivado
} 
cimiento de los Derechos Esenciales que emanan de la naturaleza humana como límite al ejercicio de la soberanía y el Control de Constitucionalidad.

Son, por su parte, garantías concretas, aquellos instrumentos reactivos que se ofrecen a las personas para que, en cada caso singular en que se repute, ocurrida una vulneración de un Derecho Fundamental, puedan acudir a ellos y obtener la preservación de su derecho o el reestablecimiento del mismo. Su finalidad no es prevenir una eventual actuación de los poderes públicos que, con carácter general, pretenda menoscabar la eficacia o alcance de los Derechos Fundamentales, sino proveer a cada persona la facultad de reaccionar ante las vulneraciones a sus Derechos Fundamentales. ${ }^{11}$ Se las denomina también garantías jurisdiccionales, pues todas ellas importan la posibilidad de requerir ante órganos de esa naturaleza la preservación o reestablecimiento del derecho conculcado.

En el Derecho chileno, el contribuyente se encuentra protegido en los tres niveles ya mencionados, esto es, mediante la consagración de enunciados iusfundamentales, ${ }^{12}$ referidos a inmunidades ante la potestad del Estado para imponer tributos, y a través de garantías abstractas y concretas.

En efecto, la Constitución Política de la República de Chile asegura a todas las personas, en su artículo 19 No $20,{ }^{13}$ la igual repartición de los tributos y demás

opiniones del Tribunal Constitucional alemán cuyo eje fundamental reproducimos a continuación: La experiencia ha enseñado que incluso el legislador puede emitir leyes injustas y que, en consecuencia, la administración de justicia deberá estar armada contra un posible desarrollo de semejantes prácticas. Entendido así el contenido esencial consiste en una conciencia de que existen elementos de un derecho que ningún legislador puede suprimir o restringir y que es aquello que debe pervivir ante cualquier regulación del legislador, evitando que ésta desfigure o difumine los límites del derecho hasta hacerlo irreconocible, tal como lo expresó el Tribunal Constitucional español en su sentencia 11/81 recaída sobre el caso conocido como Decreto Ley de Huelga. Es la base fundamental del carácter Contramayoritario de los Derechos Fundamentales, esto es, aquello a lo cual se tiende derecho a hacer, aun cuando la mayoría piense que hacerlo estaría mal, e incluso cuando la mayoría pudiese estar peor porque ese algo se haga. BoRDALÍ (2002) p. 63.

Por ello, se podría decir que lo propio de los Derechos Fundamentales y su núcleo esencial, es su resistencia -garantizada por la Constitución - frente a una intervención legislativa llevada a cabo, en exclusiva, según consideraciones de utilidad social o interés general. Jimenéz F. (1999) p. 26.

${ }^{11}$ García (1994) p. 41.

${ }^{12}$ Entendemos a los enunciados de Derechos Fundamentales como "aquellos enunciados de la Constitución que tipifican derechos fundamentales". AleXy (1993) p. 63.

${ }^{13}$ La citada disposición expresa: "La Constitución asegura a todas las personas: La igual repartición de los tributos en proporción a las rentas o en la progresión of forma que fije la ley, y la igual repartición de las demás cargas públicas.

En ningún caso la ley podrá establecer tributos manifiestamente desproporcionados o injustos.

Los tributos que se recauden, cualquiera que sea su naturaleza, ingresarán al patrimonio de la Nación y no podrán estar afectos a un destino determinado.

Sin embargo, la ley podrá autorizar que determinados tributos puedan estar afectados a fines propios de la defensa nacional. Asimismo, podrá autorizar que los que gravan actividades o bienes que tengan una clara identificación 
cargas públicas. Con respecto a los tributos, y a modo de garantías de los contribuyentes, la Constitución en la disposición citada fija una serie de principios y reglas tales como el principio de la igual repartición, la reserva legal tributaria, los principios de justicia y proporcionalidad y la regla de la no afectación específica o neutralidad tributaria.

Puntualmente la Constitución, en el inciso primero del artículo en comento, concreta el principio de igualdad en materia de cargas públicas. Señala que se asegura a todas las personas: la igual reparticipación de los tributos y demás cargas públicas. ${ }^{14}$ Esta igualdad, en definitiva, no es más que una reiteración específicamente referida al ámbito en cuestión de la norma general de la igualdad ante la ley, garante de la isonomía, contenida en el artículo 19 No $2^{15}$ de la Constitución, y mediante la cual se prohíben aquellas discriminaciones injustas o irracionales. ${ }^{16}$ Sin embargo, es necesario tener presente que la capacidad de imponer cargas públicas no se vincula en la actualidad solamente con la necesidad de financiar las actividades permanentes del Estado, sino que también puede ser utilizada como herramienta de desincentivo o promoción de algunas actividades en tanto se avengan al programa político vigente, por ello la mera isonomía general se ve en esta materia robustecida por la introducción del criterio de la capacidad contributiva como parámetro del juicio de igualdad. ${ }^{17}$

La reserva legal en materia tributaria - por su parte-consiste en que solamente el legislador, con exclusión de otras autoridades y fuentes del Derecho, puede establecer, modificar, suprimir o modificar tributos, entendiendo que lo anterior se extiende a la totalidad de la relación tributaria que existe entre Estado acreedor y contribuyente deudor. ${ }^{18}$ En este sentido, el Tribunal Constitucional chileno ha manifestado: la Constitución Politica, respetuosa de los derechos esenciales que emanan de la naturaleza humana, ha sido extremadamente cuidadosa en cuanto a la regulación de los tributos, requiriendo no sólo que los elementos esenciales de una obligación tributaria queden comprendidos en la ley misma, sino también que ésta

\footnotetext{
regional o local puedan ser aplicados, dentro de los marcos que la misma ley señale, por las autoridades regionales o comunales para el financiamiento de obras de desarrollo".

${ }^{14}$ Para la Constitución chilena existe una relación de género a especie entre cargas públicas y tributos, siendo las primeras la categoría genérica y los segundos una especie de aquéllas. Tal conclusión se extrae del enunciado constitucional pues éste se refiere a: los tributos y demás cargas públicas.

${ }^{15}$ Este artículo señala que la Constitución asegura a todas las personas: $2^{o}$. La igualdad ante la ley. En Chile no hay persona ni grupos privilegiados. En Chile no hay esclavos y el que pise su territorio queda libre. Hombres $y$ mujeres son iguales ante la ley.

Ni la ley ni autoridad alguna podrán establecer diferencias arbitrarias.

${ }^{16}$ Fernández M. (2000) p. 359.

${ }^{17}$ Evans de la Cuadra (1997) p. 52.

${ }^{18}$ Ibídem, p. 51.
} 
se genere de acuerdo con las exigencias que la misma Constitución puntualiza. Por lo mismo, deben tenerse presente las normas constitucionales contenidas en el No 2 del artículo 60 que establece que son materias de ley "Las que la Constitución exija que sean reguladas por una ley"; en el numero $1^{\circ}$ del inciso cuarto, del artículo 62, que dispone que corresponderá al Presidente de la República la iniciativa exclusiva para las leyes que tengan por objeto "imponer, suprimir, reducir o condonar tributos de cualquier clase o naturaleza, establecer exenciones o modificar las existentes, y determinar su forma, proporcionalidad o progresión”; en el No 14 del artículo 60 que preceptúa que son materias de ley "Las demás que la Constitución señale de iniciativa exclusiva del Presidente de la República"; en la primera parte del inciso segundo del articulo 60 que determina que "Las leyes sobre tributos de cualquier clase que sean, sobre los presupuestos de la administración pública y sobre reclutamiento, sólo pueden tener origen en la Cámara de Diputados"; en el artículo 61, inciso segundo, que dispone que una autorización del Congreso Nacional al Presidente de la República para dictar disposiciones sobre materias que correspondan al dominio de la ley, "no podrá extenderse ... a materias comprendidas en las garantías constitucionales"; y en los artículos $6^{\circ}$ y $7^{\circ}$, que consagran los principios fundamentales aplicables a las actuaciones de los órganos del Estado y a su sometimiento a la preceptiva constitucional. ${ }^{19}$

La Constitución chilena también fija dos parámetros alternativos para la determinación de la relación entre la base imponible y la tasa del tributo constituidos por los criterios de proporcionalidad y progresividad. En virtud del primero, la ley puede establecer que respecto de un tributo la tasa consistirá en un porcentaje fijo aplicable a la base imponible, mientras que el segundo autoriza la configuración de tasas progresivamente más altas dependiendo de la magnitud de la base imponible de cada contribuyente, esto es también de competencia exclusiva de la ley. ${ }^{20}$

Además, se establecen también dos parámetros sustantivos destinados a limitar el monto de las prestaciones que por concepto de tributos deban efectuar los contribuyentes, tales son los principios de justicia y proporcionalidad. Sobre el particular, la Constitución señala: en ningún caso la ley podrá establecer tributos manifiestamente desproporcionados o injustos.

En general, se ha entendido que un tributo resulta manifiestamente desproporcionado cuando deviene en confiscatorio, es decir, cuando mediante la imposición de

\footnotetext{
${ }^{19}$ Sentencia del Tribunal Constitucional Rol No 247 (1996). Respecto de esta sentencia es necesario tener presente que fue dictada en 1996, pues en el año 2005 producto de una significativa reforma constitucional las disposiciones citadas vieron alterado el número de artículo al cual se asignan, más no su contenido.

${ }^{20}$ Respecto de los tributos fijos, esto es aquellos que establecen el deber de pago de una suma determinada, no existe alusión alguna en el texto constitucional, por lo que se ha entendido que no se encuentran prohibidos en tanto no impliquen una afectación del resto de los principios que regulan la potestad tributaria.
} 
un tributo el Estado se apropia de una parte cuantitativamente desproporcionada del patrimonio o renta del contribuyente. Como lo ha expresado el Tribunal Constitucional: cabe tener presente que al no encontrarse contemplado por la Constitución o la ley un concepto de lo que se entiende por manifiestamente desproporcionado o injusto, tal determinación debe quedar entregada a lo que la justicia constitucional decida, caso a caso, en materia de proyectos de ley o leyes. (...) la desproporcionalidad o injusticia de la tasa del tributo es difícil de determinar, pues existen múltiples factores, todos de hecho, que inciden en su calificación". Mención expresa hace el Tribunal (Refiriéndose a la sentencia Rol: 219) de estos factores: la capacidad de pago del contribuyente, la calificación del bien como de uso o consumo habitual o de carácter suntuario o prescindible o, si con su imposición se impide el desarrollo de una actividad económica. (Considerando 80) Complementando lo anterior, ha señalado que en ningún caso, el constituyente fijó un monto o rango para los gravámenes que afectan a las rentas, pero si le fijó un límite. Éste impide al legislador establecer desproporciones injustificables o irracionales. En la citada sentencia, este Tribunal reflexionó en su considerando $9^{\circ}$, en torno a que "...no puede dejar de señalar que un impuesto indirecto podría, entre otras situaciones, ser manifiestamente desproporcionado o injusto si con su imposición o monto se impide del todo o se limita de tal manera que hace imposible el libre ejercicio de una actividad económica o impide la adquisición del dominio de los bienes a que afecte el impuesto. ${ }^{21}$ No obstante lo anterior, el propio Tribunal Constitucional ha señalado que se entenderá que un tributo es confiscatorio cuando hace imposible el libre ejercicio de una actividad económica o cuando impide la adquisición del dominio de los bienes afectos. ${ }^{22}$ Lo será también -en opinión de la doctrina-cuando sobrepase los criterios de proporcionalidad fijados en el derecho comparado e internacional. ${ }^{23}$

Cabe hacer presente que la Constitución prohíbe la desproporción manifiesta del tributo, no la simple desproporción. Por ello, como lo señala Cea Egaña ${ }^{24}$, secundado por alguna sentencia del Tribunal Constitucional25, pareciera que la

\footnotetext{
${ }^{21}$ Sentencia del Tribunal Constitucional Rol No 280, Considerando 18, (1998).

22 Ídem.

${ }^{23}$ Cea Egaña (2003) p. 476.

${ }^{24}$ Ibídem, p. 477.

${ }^{25}$ La ya citada sentencia Rol 280 expresa en su considerando No 19 expresó: La palabra "manifiestamente" se define como "Descubierto, patente, claro", y la expresión "desproporcionado", significa que no es proporcionado.

El Constituyente prohibe que el tributo sea "manifiestamente desproporcionado" con lo cual reconoce que la desproporción justificada no violenta el principio de igualdad tributaria.

Por tanto, el Constituyente se guardó de restringir en exceso la autonomía del legislador, y le impuso un límite que sólo impide las desproporciones o injusticias "manifiestas", esto es, aquellas que resultan burdas, exageradas e injustificables. Las restricciones al legislador en esta materia son, entonces, particularmente excepcionales. Ello implica
} 
Constitución admitiría la desproporción de ciertos tributos en tanto ella fuere justificada, haciendo, de paso, sinónimos los conceptos de "manifiestamente desproporcionados" con "injustificadamente desproporcionados".

Por su parte, se ha considerado que un tributo será injusto cuando resulta inconducente a la finalidad perseguida con su establecimiento, carente de objetivo conocido, ha sido impuestos sin comprobar si es necesario, etc. ${ }^{26}$ La determinación de este límite constitucional a la imposición de tributos comparte la indeterminación que afecta al límite de la desproporción manifiesta, por lo que, nuevamente, se ha estimado que la evaluación de su cumplimiento dependerá de la casuística. ${ }^{27}$

Por último, la Constitución chilena establece una garantía que protege al contribuyente de la imposición indiscriminada de tributos para fines demagógicos y/o populistas, ésta es la regla de la no afectación de los tributos a fines específicos, también denominada por Zavala Ortiz - muy certeramente a nuestro juicio-como regla de la neutralidad impositiva, ${ }^{28}$ la cual señala que cualquier suma recaudada por concepto de tributos ingresa directamente al erario nacional y no podrá ser destinada a fines específicos. Esta regla tiene tres excepciones establecidas en la propia Constitución referidas a aquellos tributos que la ley destine a fines propios de la defensa nacional, a los tributos que gravan actividades o bienes de clara identificación local o regional, que pueden ser destinados específicamente para financiar obras de desarrollo regional o local respectivamente y a las normas preconstitucionales que establezcan un destino específico mientras no sean expresamente derogadas, según lo dispone la disposición transitoria sexta de la Constitución.

Conjuntamente con las garantías tributarias, el mismo artículo señala la garantía de la igual repartición de las demás cargas públicas. Por carga pública debe entenderse: toda prestación de hacer o de dar no pecuniaria que el Estado impone a las personas, sin que a cambio de ella se reciba una contraprestación directa. Las cargas públicas pueden ser de dos tipos: reales y personales. Las cargas personales obligan a realizar una prestación personal, por ejemplo el servicio mi-

\footnotetext{
que la defensa de la supremacia constitucional en este ámbito, ha de circunscribirse a evitar las desproporciones o injusticias tributarias que traspasen todos los limites de lo razonable y prudente.

La desproporción o injusticia tiene que fluir de las propias preceptivas legales, cualesquiera sean los hechos que digan relación con las materias previstas en ellas. Dicho, todavia de otra manera, la desproporción o injusticia tiene que ser tan evidente que, cualesquiera sean los hechos, ella resulte patente y clara en la propia disposición legal.

${ }^{26}$ Cea Egaña (2003) p. 476.

${ }^{27}$ Ídem.

${ }^{28}$ Zavala (2009) p. 12. En este mismo texto puede encontrarse también una relación de las garantías constitucionales del contribuyente, desde luego, mucho mejor lograda y más rigurosa que la efectuada por nosotros.
} 
litar obligatorio. Las cargas reales gravan los bienes de una persona, por ejemplo las requisiciones de bienes, las servidumbres de utilidad pública y cualquier otra que no consista en el pago de una suma de dinero..$^{29}$ El fundamento de las cargas públicas reales es la función social de la propiedad.

Todas las anteriores reglas y principios constituyen normas que vinculan directamente a los poderes del Estado. Positivamente, en cuanto programan y orientan el contenido de sus decisiones, a aquellos dotados de la potestad de imponer tributos, y negativamente a todos aquellos a quienes está prohibida tal actividad. Por este motivo, su cumplimiento se procura mediante mecanismos de control de la producción normativa, sea mediante el control de constitucionalidad de las leyes, previo y represivo, en tanto vinculación positiva o mediante la acción de nulidad de Derecho Público y el control de constitucionalidad de la potestad decretal, en tanto vinculación negativa. Sin perjuicio de lo anterior, y tal como lo señalásemos al caracterizar la diferencia entre garantías abstractas y concretas, pese a que los mecanismos ya señalados tienen principalmente por objeto resguardar la supremacía de la Constitución y la coherencia del ordenamiento jurídico -en casos concretos- pueden también favorecer intereses de particulares por actos que infrinjan las disposiciones constitucionales, por ejemplo, a través de la denominada acción de inaplicabilidad por inconstitucionalidad, en virtud de la cual el Tribunal Constitucional puede ordenar que un precepto legal contrario a la Carta Fundamental no sea empleado en la resolución de un litigio por el juez de la instancia.

En síntesis, la Constitución chilena dota al contribuyente de un amplio elenco de garantías, sea mediante la simple consagración de reglas y principios en disposiciones iusfundamentales o a través de garantías abstractas. Sin embargo, pareciera que no le asigna garantías concretas, pues la acción constitucional que por excelencia procede ante la conculcación de un derecho fundamental, el recurso de protección -equivalente al recurso de amparo de Derechos Fundamentales del Derecho Comparado- no comprende las hipótesis de violación de las normas contenidas en el artículo 19 No 20.

Empero, mediante una revisión sistemática de la Constitución Política de la República de Chile, podremos concluir además que el contribuyente se encuentra premunido de otra garantía, esta vez jurisdiccional, no anulatoria pero sí reparatoria, en caso de violación por parte del legislador de las normas que disciplinan su actividad. Se trata de la responsabilidad patrimonial del Estado Legislador por leyes declaradas inconstitucionales. Tópico en el que profundizaremos a continuación.

${ }^{29}$ Henríquez y NúNez (2007) p. 186. 
3. El EFECTO DE LAS SENTENCIAS DE INCONSTITUCIONALIDAD

PRONUNCIADAS POR EL TRIBUNAL CONSTITUCIONAL CHILENO:

INCONSTITUCIONALIDAD SIN EFECTO RETROACTIVO Y SU RELACIÓN CON

LA RESPONSABILIDAD PATRIMONIAL DEL ESTADO LEGISLADOR

\section{a) La relación entre inconstitucionalidad, nulidad y el efecto retroactivo}

En el año 2005 se promulgó y entró en vigencia la ley No 20.050 sobre reforma constitucional, norma que introdujo un número considerable de modificaciones a la Constitución Política de la República de Chile. Entre ellas, a efectos de nuestro trabajo, reviste capital importancia la nueva competencia que se confirió al Tribunal Constitucional para declarar la inconstitucionalidad, en abstracto y con efectos generales, de un precepto legal vigente, es decir, su abrogación. Tal atribución constituye una novedad sin precedentes en el sistema chileno de Justicia Constitucional.

Tal declaración, procedente de oficio o mediante requerimiento de un legitimado activo, requiere que previamente el mismo Tribunal Constitucional haya pronunciado sobre la misma norma una sentencia de inconstitucionalidad con efecto particular en control concreto.

La propia Constitución, en su artículo No 94, precisa los efectos que tendrá esta sentencia, señalando que, a partir de su publicación en el Diario Oficial, el precepto legal objeto de la declaración se entenderá derogado ${ }^{30}$ y que tal resolución no tendrá efecto retroactivo.

Para la cabal comprensión de este precepto, y de sus consecuencias, resulta sumamente útil efectuar previamente algunas distinciones conceptuales. En el ámbito de la invalidez de las normas se distingue entre: régimen de validez de las

\footnotetext{
30 "La derogación entonces, tiene un doble carácter, por una parte tiene el de acción legislativa, como acto normativo en sentido negativo, ya que depura y modifica el orden, y por la otra es también el efecto que se puede producir por disposición expresa del órgano creador o por la expedición de una nueva regulación que por la materia que regula sustituye a la anterior. La derogación como efecto, determina la pérdida de la vigencia de una norma de manera definitiva o permitiendo la subsistencia de una cierta eficacia para ciertos casos. La norma derogada es aquella a la que se refiere la norma derogatoria cuyo contenido es la obligación de no aplicar la primera por la pérdida de su vigencia.

La derogación como acción es el procedimiento utilizado para eliminar ciertas normas del orden jurídico y evitar así su futura aplicación, lo cual se justifica en virtud de algunas razones de oportunidad o de seguridad jurídica. Las prescripciones que tienen por objeto poner fin a la vigencia de otras normas o sustituirlas, e impedir su aplicación son denominadas normas derogatorias. Alchourrón y Bulygin denominan "acto de rechazo" a la acción realizada por la autoridad competente, la cual junto con la eliminación de la norma a partir de dicho acto constituyen los componentes de la derogación, en otras palabras, la acción y el efecto. De modo que la acción constituye un acto legislativo, el efecto consiste en privar a la norma de su aplicabilidad, y mientras la primera es modificable en tanto no se realizan las condiciones que prevé la norma derogatoria, el segundo es permanente. Asimismo se puede decir que como acción, la derogación es expresa, pero como efecto es consecuencia o bien de un acto expreso, o de la incompatibilidad entre dos normas." HUERTA (2001) p. 832.
} 
normas, régimen de invalidación y régimen de eficacia de los actos declarativos de invalidez. El primero de los conceptos alude al conjunto de condiciones establecidas por las normas sobre producción jurídica (normas secundarias según el esquema de Hart) para la validez de las leyes y los actos legislativos. El segundo alude a quien o quienes pertenece la competencia para enjuiciar la validez de la ley y en que condiciones puede hacerlo. Y el tercero se refiere a los efectos jurídicos que se atribuyen a los eventuales actos declarativos de invalidez de las leyes. ${ }^{31}$

Como puede apreciarse, y puesto que retroactividad es de la esencia de la nulidad, el artículo No 94 de la Constitución chilena, al atribuir efectos derogatorios a la declaración de inconstitucionalidad, establece una manifiesta separación entre los conceptos de inconstitucionalidad de la norma y la nulidad de aquélla, es decir, una inconstitucionalidad sin nulidad con efectos plenos. Lo cual implica una clara opción por tal régimen específico de eficacia de los actos declarativos de invalidez de una norma infraconstitucional, similar, en parte, al modelo propuesto por Kelsen, para quien los efectos de una declaración de inconstitucionalidad debían ser siempre ex nunc y erga omnes, los mismos de una ley, pues para el jurista vienés -dentro de su concepción del Tribunal Constitucional como legislador negativo- la anulación de una ley no debía ser más que la elaboración de la misma con signo negativo. ${ }^{32}$

Como certeramente lo explica Gascón Abellán, la determinación de los efectos jurídicos que se atribuirán a eventuales declaraciones de inconstitucionalidad, constituye una decisión de diseño constitucional independiente de la opción por un régimen específico de validez de las normas subconstitucionales o de invalidación de aquéllas. Así, un mismo régimen de validez y/o invalidación podría ir acompañado perfectamente de un diferente régimen de invalidación. ${ }^{33}$ Sin embargo la coherencia del sistema no puede soslayar los efectos que se deriven de tal opción.

Un régimen de invalidación que identifique la declaración de inconstitucionalidad de la norma con su nulidad deberá reconocer necesariamente, entre otros, dos clases de efectos: uno respecto de las fuentes del Derecho y otro respecto de los actos celebrados al amparo de la norma mientras permanecía vigente.

Respecto de las fuentes del Derecho, la declaración de inconstitucionalidad de una norma vigente con efectos generales importa necesariamente su expulsión del ordenamiento jurídico, esto es su supresión como fuente del Derecho. Ello siempre ocurrirá, sea o no que el régimen de eficacia del acto declarativo tenga efecto retroactivo.

${ }^{31}$ GASCÓN (1997) p. 134.

${ }^{32}$ Fernández J. (2007) p. 30.

${ }^{33}$ GASCÓN (1997) p. 137. 
No obstante, respecto a los actos celebrados al amparo de las normas declaradas inconstitucionales y anuladas, es menester recordar que lo propio de una declaración de nulidad es su efecto retroactivo. Es decir, lo declarado nulo, a partir del momento en que acontece el vicio de nulidad, no es apto para producir ningún tipo de relación jurídica, por tanto quedan sin efecto todas las prestaciones y actos ejecutados a su amparo debiendo las partes intervinientes restituir en especie o equivalencia lo percibido con ocasión del acto nulo. Por ello, la principal consecuencia práctica que se produce merced de la declaración de inconstitucionalidad y nulidad de una ley será la producida sobre los actos ejecutados bajo la aparente validez de la norma anulada.

Según Fernández Rodríguez, las diferencias entre la nulidad general, descrita por la teoría del Derecho, y la nulidad como efecto del control abstracto de constitucionalidad, serían mínimas. En efecto, la nulidad como categoría general, consiste en una ineficacia automática, originaria, estructural, e insanable. ${ }^{34} \mathrm{~A}$ la que deriva de la acción de inconstitucionalidad se le pueden aplicar los caracteres de automática, pues su pronunciamiento es -en un Estado Constitucional de Derecho- declarativo, originario e insanable, pero no resulta estructural, pues no se origina en un defecto estructural del acto declarado nulo, sino en su fidelidad al programa sustancial y procedimental de producción normativa establecido en la Constitución.

Considerando lo anterior, fácilmente podemos imaginar los efectos que produciría respecto de los actos celebrados a su amparo la declaración inconstitucionalidad de una ley con efecto retroactivo.

Entre ellos - por ejemplo- podríamos contar los que se producirían fundamentalmente para el funcionamiento del poder público. En efecto, si la declarada inconstitucional es una norma que confiere competencias a un órgano de Estado, todos los actos ejecutados por ese órgano en aplicación de dicha ley, no tendrían valor alguno. Por otra parte, si lo es una norma que define las vías de interacción entre los órganos del Estado y particulares, como las normas que determinan las pruebas admisibles en juicio, en tal caso, se extinguiría la base de sentencias fundadas en pruebas posteriormente declaradas inconstitucionales.

Además, podrían producirse otros efectos, esta vez sobre las fuentes del Derecho y que comprometerían gravemente la certeza jurídica.

En efecto, de conformidad al principio cronológico de solución de conflictos normativos una norma posterior que verse sobre la misma materia tiene capacidad de derogar a otra anterior de igual o inferior jerarquía. Piénsese entonces en una ley que establece un estatuto para ciertos actos, sean de particulares o de entes

${ }^{34}$ FernándeZ J. (2007) p. 124. 
públicos, y que aquélla es derogada por una norma posterior que regula la misma materia. Ahora bien, si esta segunda ley es anulada por una declaración de inconstitucionalidad con tal efecto, significaría que la primera ley nunca fue derogada y que estuvo, por lo tanto, permanentemente vigente. ${ }^{35} \mathrm{Si}$ la regla general indica que los actos deben someterse a la ley vigente al momento de su celebración, en un caso como éste: ¿A cuál de las dos leyes vigentes deberían someterse dichos actos? O bien, ¿̇debiera, sin más, recuperar su vigencia la norma derogada por el precepto invalidado? ${ }^{36}$

\section{b) Algunas alternativas en el Derecho Comparado}

Habida cuenta de lo anterior, pareciera ser que existen poderosas razones para optar por un régimen de eficacia de los actos de invalidación que separe inconstitucionalidad y nulidad. Cuestión que ha sido analizada y decidida también en el Derecho Comparado.

Se suele citar como primer antecedente que da cuenta de la necesidad de afrontar este problema en la jurisdicción constitucional a la sentencia Linkletter vs. Walker ${ }^{37}$ pronunciada por la Corte Suprema de los Estados Unidos de América en 1965. En ella, tras analizar las ventajas e inconvenientes de la retroactividad en el caso que se conocía, el juzgador opta por resolver que los efectos de la sentencia estimatoria se producirán a partir de la fecha de la misma. ${ }^{38}$ Tal doctrina ha impactado de diversas formas los regímenes de eficacia de los actos declarativos de invalidez de normas legales en las distintas jurisdicciones constitucionales.

\footnotetext{
${ }^{35}$ En dicho caso, cabría preguntarse si la declaración de invalidez de la norma derogatoria podría producir la reviviscencia de la norma derogada, o si debe entenderse que nunca fue derogada. La respuesta de Alchourrón y Bulygin es que cuando la derogación es realizada por una autoridad incompetente en principio dicho acto carece de efectos jurídicos, de modo que no se produce la eliminación de la norma. Huerta (2001) p. 831.

${ }^{36}$ Problemas como éste requieren una solución. Por ejemplo la Constitución de Austria de 1920, precaviendo casos como el señalado dispone en su artículo 140.6: Anulada por el Tribunal Constitucional una ley como anticonstitucional, volverán a entrar en vigor el día mismo en que surta efecto la derogación, a menos que el fallo haya dispuesto otra cosa, las disposiciones legales que hubiesen sido derogadas por la ley que el Tribunal haya declarado anticonstitucional. Se deberá especificar, además, en la publicación relativa a la anulación de la ley si vuelve a entrar en vigor alguna disposición legal y en caso afirmativo, cuáles.

${ }^{37}$ En este caso, un condenado mediante sentencia judicial, demandó a la Corte Suprema la anulación del juicio debido a que con posterioridad a su condena el mismo tribunal en la sentencia conocida como Mapp de 1961 estimó que las mismas pruebas empleadas para probar la culpabilidad de Linkletter resultaban atentatorias al principio del debido proceso y, por tanto, inconstitucionales. En dicha oportunidad el tribunal señaló que la aplicación retroactiva de la doctrina que consideraba ilegítimas ciertas pruebas "abrumaría hasta el extremo a la administración de justicia”, además a la época sería imposible contar con una serie de pruebas que habrían conducido igualmente a una sentencia condenatoria.
}

${ }^{38}$ Por ejemplo, citan esta sentencia: Fernández J. (2007) y García de Enterria (2007). 
Por ejemplo, algunos sistemas permiten que sea el propio juez constitucional, quien determine en cada caso cuales serán los efectos que en cuanto al tiempo tendrán sus sentencias, eso sí, presumiendo ante un eventual silencio del sentenciador, el efecto pro futuro. Tal es el caso del Derecho colombiano, en donde el artículo No 45 de la Ley Estatutaria de la Administración de Justicia de Colombia determina que: Las sentencias que profiera la Corte Constitucional sobre los actos sujetos a su control en los términos del artículo 241 de la Constitución Política tienen efectos hacia el futuro a menos que la Corte resuelva lo contrario.

Otros admiten el efecto anulatorio retroactivo de la sentencia de inconstitucionalidad, pero dejando a salvo las situaciones consumadas ${ }^{39}$. Así ocurre en virtud de lo dispuesto por el artículo 140.7 de la Constitución de Austria de 1920, que señala:

Anulada una ley como inconstitucional o pronunciada sentencia por el Tribunal Constitucional, conforme al párrafo 4, en el sentido de que una ley es anticonstitucional, quedarán vinculados a dicho fallo cualesquiera tribunales y órganos administrativos. Sin embargo, se seguirá aplicando la ley en cuestión a las situaciones de hecho consumadas antes de la anulación (die vor der Aufhebung verwirklichten Tatbestande), excepto aquella que haya dado origen al fallo, si el Tribunal Constitucional no hubiere dispuesto otra cosa en su fallo derogatorio. Si el Tribunal Constitucional hubiese fijado en dicho fallo un plazo conforme a lo previsto en el párrafo 5, la ley se aplicará a todos los hechos que se consumen antes de que expire el plazo, con excepción precisamente del caso que dio origen a la sentencia.

Una solución similar aporta la Constitución de Portugal. Su artículo 282 establece que:

La declaración de inconstitucionalidad o de ilegalidad con fuerza general de obligar surte efectos desde la entrada en vigor de la norma declarada inconstitucional (...) y determina el restablecimiento de las normas que, eventualmente, esa declaración haya derogado. (...)Se exceptúan los casos juzgados, salvo decisión contraria del Tribunal Constitucional, cuando la norma se refiera a materia penal, disciplinaria o de ilícito de mera infracción social y sea de contenido menos favorable al imputado.

La Constitución de Ecuador, por su parte, establece un sistema similar al chileno, de categórica prohibición del efecto retroactivo de la declaración de inconstitucionalidad. En efecto, su artículo 278 expresa:

\footnotetext{
${ }^{39}$ Sin embargo, debido a que la propia Constitución establece la posibilidad de que el Tribunal Constitucional así los disponga, en alguna oportunidad por medio de una sentencia se ha extendido el efecto anulatorio incluso a los actos consumados con anterioridad a la dictación del fallo. Tal fue el caso de la sentencia de 24 de enero de 1997 sobre el impuesto de sociedades, en la cual se ordenó que los efectos de la sentencia de inconstitucionalidad se aplicaran incluso respecto de los casos que habían sido decididos en aplicación de la norma impugnada. SCHÄFFER, (1998) p. 38.
} 
La declaratoria de inconstitucionalidad causará ejecutoria y será promulgada en el Registro Oficial. Entrará en vigencia desde la fecha de su promulgación y dejará sin efecto la disposición o el acto declarado inconstitucional. La declaratoria no tendrá efecto retroactivo, ni respecto de ella habrá recurso alguno.

Por su parte, sobre la materia, resulta llamativo e interesante el caso español. La Constitución española no define los efectos en el tiempo de las sentencias estimativas de inconstitucionalidad. Es la Ley Orgánica del tribunal en su artículo 39.1 la que entrega algunas pautas al respecto, expresando:

Cuando una sentencia declare la inconstitucionalidad, declarará igualmente la nulidad de los preceptos impugnados, asi como, en su caso, la de aquellos otros de la misma ley, disposición o acto con fuerza de ley a los que deba extenderse por conexión o consecuencia".

De la lectura de este precepto pareciera desprenderse que la declaración de nulidad es un componente necesario de las sentencias de inconstitucionalidad. Sin embargo, en 1989 a través de la sentencia STC/45 el Tribunal Constitucional español inauguró una doctrina que permanece vigente hasta hoy y en donde se rompe la vinculación antes indicada.

En efecto, dicha sentencia reza en su fundamento jurídico No 11:

En lo que toca a los efectos hemos de comenzar por recordar que, de acuerdo a lo dispuesto en la Ley Orgánica de este Tribunal (Art. 39.1) las disposiciones consideradas inconstitucionales han de ser declaradas nulas, declaración que tiene efectos generales a partir de su publicación en el Boletín Oficial del Estado (Art. 38.1 LOTC) y que en cuanto comporta la inmediata y definitiva expulsión del ordenamiento de los preceptos afectados ( STC 19/1987 Fundamento jurídico $N^{\circ}$ G) impide la aplicación de los mismos desde el momento antes indicado, pues la Ley Orgánica no faculta a este Tribunal, a diferencia de lo que en algún otro sistema ocurre, para aplazar o diferir el momento de efectividad de la nulidad.

Ni esa vinculación entre inconstitucionalidad y nulidad es, sin embargo, siempre necesaria, ni los efectos de la nulidad en lo que toca al pasado vienen definidos por la ley, que deja a este Tribunal la tarea de precisar su alcance en cada caso, dado que la categoría de la nulidad no tiene el mismo contenido en los distintos sectores del ordenamiento.

La conexión entre inconstitucionalidad y nulidad quiebra, entre otros casos, en aquellos en que la razón de la inconstitucionalidad del precepto reside, no en determinación textual alguna de éste, sino en su omisión.

Esta sentencia ha sido duramente criticada por un sector de la doctrina. Por ejemplo, Balaguer Callejón ha señalado que, pese al texto expreso de su Ley Orgánica, el Tribunal Constitucional ha seguido un planteamiento diferente al de los efectos de las sentencias dictados en procesos de inconstitucionalidad, que está en función de un concepto de inconstitucionalidad de la ley no basado en los vicios, sino en una disociación de dos términos, la eficacia de la ley y la eficacia 
de la sentencia, haciendo que la sentencia del tribunal produzca efectos desde su publicación y que la ley despliegue sólo los establecidos en la sentencia. ${ }^{40}$

Otros autores, por su parte, han defendido la racionalidad de la citada sentencia destacando que el conflicto de constitucionalidad que resuelve era precisamente producto de una omisión del legislador, es decir un precepto que no existía pero que debía existir. Y aquello que no existe no puede ser anulado, solamente sería posible en un caso como éste denunciar la inconstitucionalidad de tal omisión. ${ }^{41}$ Sobre todo cuando se trata de una inconstitucionalidad por omisión relativa, ${ }^{42}$ esto es aquellas que con afectación del principio de igualdad, confieren prestaciones de forma injustificada solamente a algunos de todos los que se encuentran en la misma situación, pues en tales circunstancias la anulación de la prestación parcialmente concedida puede afectar Derechos Fundamentales.

\section{c) Sentencias sin efecto retroactivo y supremacía constitucional.}

La breve relación que hemos efectuado acerca del origen y justificación del efecto pro futuro de las sentencias de inconstitucionalidad sirve para ilustrar la existencia de poderosas razones para que la jurisdicción constitucional opere aplicándolo y que normas positivas lo contemplen. Inclusive, el caso español, en donde tal efecto no resulta evidente a partir de la Ley Orgánica que disciplina el funcionamiento del Tribunal Constitucional, pero a fuerza de los hechos y las circunstancias dicho tribunal se ha visto en la necesidad de adoptarlo mediante una doctrina jurisprudencial, da fe de su utilidad para el Estado Constitucional de Derecho. Sin embargo, la disociación entre inconstitucionalidad y nulidad en las sentencias estimativas no debe hacernos olvidar la lógica basilar de un Estado en el que la Constitución es la norma jurídica suprema.

Si el órgano de justicia constitucional -nos recuerda Fernández Rodríguezestima la acción procesal que busca la eliminación de la norma puesta en tela de juicio, la sentencia declarará el carácter contrario a la Carta Magna de esa norma y, como sanción anudada a tal declaración, su nulidad, con lo que la disposición será expulsada del ordenamiento jurídico con efectos retroactivos, es decir, ex tunc. La naturaleza de tal sentencia es declarativa, no constitutiva al limitarse a reconocer una situación ya existente. ${ }^{43}$ Este es un rasgo que hoy en día forma parte esencial de las sentencias estimativas de inconstitucionalidad. Tal característica,

\footnotetext{
${ }^{40}$ Ballaguer (2001) p. 162.

${ }^{41}$ Ahumada (1991) p. 190.

${ }^{42}$ Fernández J. (2007) p. 85

${ }^{43}$ Ibídem, p. 123.
} 
como vimos, no formaba parte del esquema de control de constitucionalidad de las leyes propuesto por Kelsen, en razón del temor que al autor de la teoría pura del Derecho le causaba un eventual gobierno de los jueces. ${ }^{44}$ Sin embargo, resulta un imperativo lógico del valor jurídico supremo de la Constitución, sobre todo bajo el paradigma del Estado Constitucional de Derecho y del Neoconstitucionalismo.

El vicio de una ley que contraviene la Constitución, irremediablemente se produce antes de su entrada en vigencia. Es en el momento legislativo, en alguno de sus trámites, que la ley viola el programa formal o sustancial prefijado por la Carta Fundamental. La entrada en vigencia de la norma aparentemente constitucional, marca el ingreso al sistema de una fuente del Derecho viciada producto de un vicio de inconstitucionalidad acontecido con anterioridad. En este contexto, reconocer plena y absoluta juridicidad a los efectos de una ley que adolece de inconstitucionalidad desde su entrada en vigencia hasta la sentencia que denuncia su invalidez, equivale a negar la eficacia de la Constitución durante aquel espacio de tiempo.

La nulidad es, un régimen de ineficacia indisponible exigido por la efectividad de la norma imperativa, en este caso la Constitución. Así ya lo sostenía el Juez Marshall en el conocido caso Marbury Vs. Madison:

Quienes niegan el principio de que la Corte debe considerar la Constitución como la ley suprema, se ven reducidos a la necesidad de sostener que los tribunales deben cerrar los ojos a la Constitución y mirar sólo a la ley. Esta doctrina subvertiría los fundamentos mismos de toda constitución escrita. Equivaldría a declarar que una ley totalmente nula conforme a los principios y teorías de nuestro gobierno es, en la práctica, completamente obligatoria. Significaría sostener que si el Congreso actúa de un modo que le está expresamente prohibido la ley asi sancionada sería, no obstante tal prohibición, eficaz. Estaría confiriendo práctica y realmente al Congreso una omnipotencia total con el mismo aliento con el cual profesa la restricción de sus poderes dentro de limites estrechos. Equivaldría a establecer al mismo tiempo los límites y el poder de transgredirlos a discreción.

Por lo tanto, la necesidad de moderar los efectos negativos que eventualmente se producirían producto de la anulación de una ley mediante una sentencia de inconstitucionalidad, no puede importar la supresión del efecto esencial de la declaración de invalidez de una norma infraconstitucional, o al menos no sin violar la supremacía de la Constitución. Si bien, el efecto pro futuro de ciertas sentencias resulta una necesidad para la protección de los fines de todo el sistema jurídico: la

\footnotetext{
${ }^{44}$ Fernández Rodríguez sostiene que esta opción por una arquitectura concentrada y constitutiva de la justicia constitucional resultó del intento de Hans Kelsen por conciliar la necesidad de atribuir un valor normativo indirecto a la Constitución con la de evitar la proliferación de las ideas provenientes de la escuela del Derecho Libre, muy en boga a la época en que se redactaba el proyecto de la constitución austriaca de 1920, que proponían relajar el sometimiento del juez a la ley. Fernández J. (2007) p. 30.
} 
paz, la justicia y la certeza jurídica, estos mismos fines requieren que aquellos actos fundados en normas legales inválidas sean sometidos al estatuto general dispuesto para los actos antijurídicos que causan daño o perjuicios a particulares, si es que efectivamente éstos se han producido.

d) Sentencias de inconstitucionalidad sin efectos retroactivos y responsabilidad del Estado legislador

Ahora bien, revisando nuevamente la experiencia que nos aporta el Derecho Comparado, el Derecho español nos muestra un claro ejemplo de lo anterior, en donde precisamente, se ha estimado que la necesidad de proteger ciertos derechos y valores mediante las sentencias sin efectos retroactivos no excluye la posibilidad de que aquellos perjudicados por la ley nula demanden una indemnización al Estado por los daños irrogados por dicha ley. Además, la tendencia seguida por dicho sistema jurídico, que tanta influencia ha proyectado sobre el Derecho chileno, nos debe servir como anuncio de las eventuales consecuencias prácticas de la operación de un sistema de justicia constitucional en el cual la declaración de inconstitucionalidad de la ley no produce efectos retroactivos.

En efecto, la ya citada sentencia STC 45/1989 inauguró la doctrina en análisis en España la cual permanece en aplicación hasta nuestros días. Durante su vigencia diversos casos han ocurrido en los cuales la norma declarada inconstitucional en estos términos es una norma tributaria a cuyo amparo se han efectuado prestaciones pecuniarias a favor de la hacienda pública antes de dicha declaración. De la jurisprudencia del Tribunal Constitucional español en sede de amparo se desprende que aquellos contribuyentes que previamente a la declaración de inconstitucionalidad hubieran intentado recursos en contra del acto administrativo de cobro, con tal de que su resolución estuviese pendiente a la época de la sentencia del juez constitucional, se verían favorecidos por la declaratoria de inconstitucionalidad y por tanto las sentencias definitivas de los juicios en curso deberían considerar que la ley fue expulsada del ordenamiento jurídico y por tanto la obligación tributaria se veía extinguida. A contrario sensu, quienes no hubieren interpuesto recurso, o cuyo recurso ya hubiera sido fallado, no podrían beneficiarse de la sentencia del Tribunal Constitucional.

Tales efectos fueron duramente criticados por la doctrina, la que ironizando sostuvo que el Tribunal Constitucional estaba premiando a los recurrentes oportunos. 45

De la injusticia que producía esta situación y de la "desazón, en el sentido de inquietud interior, que produce fundamentar una sentencia en un precepto legal

${ }^{45}$ CHeCA (2004) p. 56. 
fundamentado nulo" a la que alude un voto disidente de los Magistrados Jiménez de Parga y Mendizábal Allende en la sentencia STC 159/97, se hizo cargo posteriormente el tribunal supremo. Afortunadamente -señala Checa González- el Tribunal Supremo reaccionó contra ella, propiciando y posibilitando un camino para obtener la restitución de lo ingresado con infracción de lo establecido por la propia Constitución, al establecer al respecto que es factible el ejercicio de la acción de responsabilidad patrimonial derivada de un acto legislativo que haya sido declarado inconstitucional, aun inclusive en el supuesto de que el proceso estuviese ya fenecido, añadiendo que la eficacia de la cosa juzgada, no es obstáculo para el ejercicio de tal acción, lo que supone, en suma, el pleno reconocimiento de que existiendo un perjuicio individualizado, concreto y claramente identificable debe procederse a su reparación. ${ }^{46}$ Única alternativa que, a nuestro juicio, resulta compatible con la fuerza normativa plena de la Constitución.

Curiosamente las sentencias que abren paso a la categórica recepción de la responsabilidad patrimonial del Estado Legislador por parte de la Jurisprudencia del Tribunal Supremo español, tienen que ver con la declaración de inconstitucionalidad de normas tributarias. Más adelante tendremos oportunidad de analizar con mayor detención los casos en cuestión, por ahora, nos interesa destacar la profunda vinculación entre no sólo la declaración de inconstitucionalidad de la ley y la responsabilidad patrimonial del Estado Legislador, toda vez que aquélla es la principal fuente de imputación del deber reparatorio en virtud de la antijuridicidad que constata, sino también la que existe entre esta última y el efecto irretroactivo de las sentencias de inconstitucionalidad, pues la irretroactividad de la declaración excluye la posibilidad de reparar en parte las consecuencias del pago de prestaciones inconstitucionales mediante el instituto de las restituciones mutuas, propio de la nulidad. En ese contexto, la única alternativa posible para la obtención de una reparación por daños ocasionados por situaciones de esta naturaleza sería precisamente la responsabilidad del Estado por actos del legislador.

\section{LA RESPONSABILIDAD PATRIMONIAL DEL ESTADO LEGISLADOR. DOCTRINAS A FAVOR Y EN CONTRA}

El de la responsabilidad patrimonial del Estado Legislador no es un tema nuevo ni su tratamiento pacífico en la doctrina. Su configuración supone el replanteamiento de temas con importancia capital para el Derecho. Decidir y definir como norma o principio el deber del Estado de reparar o compensar las consecuencias de un acto dañoso efectuado por sus agentes requiere un previo pronunciamien-

${ }^{46}$ Ibídem., p. 56. 
to acerca de la posibilidad jurídica de que el Estado cause daño y que aquél sea antijurídico. Tales cuestiones nos reconducen directamente a la teoría política y constitucional, a la del derecho y a la de la democracia. ${ }^{47}$

A la fecha, en nuestro sistema, la jurisprudencia acepta la existencia de una teoría restringida de la responsabilidad patrimonial del Estado, definida por normas expresas que la consagran para casos concretos, como el artículo 19 No 7 letra I a propósito del Estado Juez y el artículo 38 inciso segundo a propósito del Estado Administrador.

Respecto del ejercicio de la potestad decretal de la administración que en ejercicio de su actividad reguladora se suele acudir como defensa ante las intervenciones ablatorias de derechos a institutos que denuncian la invalidez del acto fundándose en la garantía de la reserva legal, el contenido esencial de los derechos asegurado por el artículo 19 No 26 de la Constitución, algunos derechos fundamentales especialmente el de propiedad y los requisitos que emanan de la regulación constitucional de la expropiación para la privación del derecho de dominio privado.

En este contexto la justicia ordinaria y la constitucional han dictado diversos fallos y la doctrina ha producido interesantes argumentos y conceptos.

Sin embargo, probablemente por falta de oportunidad, no existen antecedentes jurisprudenciales que se pronuncien efectivamente sobre la responsabilidad patrimonial del Estado Legislador. En efecto, cuatro sentencias son citadas con frecuencia por la doctrina tradicional como ejemplos de eventuales indicios de la aplicación de esta teoría en nuestro país. Se trata de los conocidos casos Comunidad Galletué con Fisco de Chile, Sociedad agrícola y Forestal Casagrande Ltda. con Fisco de Chile, Sociedad Agrícola Lolco Ltda. con Fisco de Chile y, recientemente, Sociedad Inmobiliaria Maullín Ltda. con Fisco de Chile.

$\mathrm{Si}$ bien las tres primeras sentencias condenaron al Estado Fisco a pagar una compensación económica, lo hicieron a causa de hechos del Estado normador, en ejercicio de la potestad decretal, más no por actos del legislador. Lo cual, si bien constituye un importante avance en la superación de la vieja y preconstitucional doctrina del "ius eminens" (con su formulación anglosajona: "the King can do not wrong"), no es coincidente con las características que presenta el tópico de la responsabilidad patrimonial del Estado Legislador. Solamente el cuarto caso, Sociedad Inmobiliaria Maullín Ltda. con Fisco de Chile, aborda la situación de perjuicios provocados por la aplicación de una ley, pero no desde una perspectiva reparatoria de la intervención ablatoria del legislador, sino a partir de la inaplicabilidad por inconstitucionalidad de normas preconstitucionales, el alcance del

${ }^{47}$ Sobre el particular véase: NúÑEZ (2009c). 
concepto función social de la propiedad, el límite a las regulaciones del dominio ${ }^{48}$ y el concepto de Regulatory Takings. ${ }^{49}$

Respecto de la doctrina, es posible sostener que en la materia, se encuentra dividida. Aylwin Azócar, ${ }^{50}$ es partidario de la tesis que sostiene la irresponsabilidad del Estado Legislador, salvo que una ley expresamente acordara lo contrario a favor de los afectados por su entrada en vigencia o aplicación. Caldera Delgado, por su parte, es de la idea que basta la existencia de un perjuicio que constituya un atropello a un derecho fundamental para que dicha ley sea además de inconstitucional, la causa de una indemnización reparatoria. ${ }^{51}$ En el mismo sentido se manifiesta Zúñiga Urbina. ${ }^{52}$

Los argumentos que sostiene la doctrina chilena para mantener la tesis de la responsabilidad patrimonial del Estado circunscrita a las esferas administrativa y judicial, son similares a los expresados por autores extranjeros los que por su claridad reproduciremos directamente.

En España, donde diversas sentencias han condenado al fisco a reparar daños causados por actos del legislador, García de Enterría sostiene que el Tribunal Supremo está reconociendo con una notable liberalidad la posibilidad de obtener indemnizaciones por los perjuicios que para los particulares pueden derivarse de la aplicación de ciertas leyes, tanto del Estado como autonómicas. Expresa que del principio de responsabilidad del Estado contenido en el artículo 9 de la Constitución española no es posible extraer una figura de responsabilidad patrimonial del Estado, sino solamente una responsabilidad de naturaleza política, y que los Tribunales contencioso-administrativos carecen de competencia para pronunciar sentencias de condena contra el Legislador. ${ }^{53}$

En el mismo sentido, también en España, se expresan las doctrinas que Jiménez Lechuga caracteriza como las teorías negativas de la responsabilidad patrimonial del Estado Legislador, las cuales - en general- sostienen que: "si el poder constituyente hubiese querido responsabilizar al poder legislativo ordinario por hechos o actos derivados de la aplicación de las leyes, hubiese debido incorporar, lógicamente, tal responsabilidad a los preceptos constitucionales en los que los regula (Título III), exactamente como lo hizo para los otros poderes del Estado

\footnotetext{
${ }^{48}$ Fermandois (2005) p. 19.

${ }^{49}$ Sobre el particular véase: Delaveau (2006) pp. 411-438.

${ }^{50}$ AyLWin (1960) p. 19.

${ }^{51}$ Caldera (1982) p. 51.

${ }^{52}$ ZuÑiga (2005).

${ }^{53}$ García de Enterría (2007).
} 
(Corona, Gobierno, Administración y Tribunales) en sus títulos respectivos. En consecuencia, si pudiendo y debiendo haber hablado, calló, es porque tal responsabilidad quiso excluir. ${ }^{54}$

Otro argumento, recurrentemente citado en contra de esta figura, es el que proviene de un fallo francés de 1835, citado por una sentencia del Consejo de Estado francés de 1938, en el cual se optó por la negativa a declarar que el Estado habría de responder patrimonialmente por el hecho del legislador argumentando que la ley al ser una norma general no afecta situaciones jurídicas de personas determinadas, sino que su aplicación beneficia o perjudica a todos por igual. Ello significa que no produciría un daño especial a algunos individuos y por tanto el Estado no tendría el deber de indemnizar aquel daño. La especialidad aquí aludida, como explica Vedel, se referiría a que el perjuicio alegado ha de estar individualizado o ser individualizable, es decir, que no afecte a la totalidad de los individuos destinatarios de la norma, pues sólo en aquel caso se lo entendería como anormal y antijurídico. ${ }^{55}$

En un sentido similar se pronuncia el destacado administrativista Rafael Bielsa quien niega tajantemente la posibilidad de responsabilizar patrimonialmente al Estado por actos del legislador, entre otros motivos porque sería imposible que éste cometiera actos antijurídicos, ni arbitrariedades. Para el autor argentino, el instituto jurídico apto para las afectaciones o privaciones al dominio sería la expropiación, sólo en los casos pertinentes en que se pueda verificar la transmisión de propiedad al patrimonio público. ${ }^{56}$

Desde una perspectiva un tanto más práctica, pero no por eso justificada, también se ha expresado que reconocer el derecho a la indemnización por actos del legislador podría paralizar la evolución legislativa por la enorme cuantía de las sumas que deberían abonarse. El progreso social -se ha dicho- no puede detenerse a causa de los intereses individuales. ${ }^{57}$ Especialmente si se considera que el legislador es uno de los poderes del Estado que no crea directamente recursos, sino sólo los redistribuye.

Contra estos argumentos y en defensa de la responsabilidad patrimonial del Estado Legislador podríamos sostener lo siguiente.

Jellinek señala que el fundamento actual de la responsabilidad del Estado en sus diversas facetas, no es otro que el Estado de Derecho y sus presupuestos, cuya finalidad última es proteger a los gobernados en sus derechos. Un Estado de Derecho "irresponsable" es una contradicción en sus propios términos. Estado de

\footnotetext{
${ }^{44}$ JiMÉNEZ F. (1999) p. 69.

${ }^{55}$ Vedel (1980) p. 323.

${ }^{56}$ BielSA (1938).

${ }^{57}$ GARCÍA H. (1992). p. 12.
} 
Derecho y responsabilidad serían, entonces, términos correlativos. Y es la propia Constitución chilena, norma suprema y directamente aplicable, conforme a su artículo $6^{\circ}$, la que consagra como base institucional de la República de Chile la responsabilidad del Estado. A este respecto es necesario hacer presente que para el caso chileno sería improcedente la crítica ya mencionada crítica de García de Enterría en orden a que el concepto responsabilidad empleado en el artículo 9 de la Constitución española no se referiría a una responsabilidad patrimonial sino sólo a una de naturaleza política, ello pues en la norma fundamental chilena, la responsabilidad política, elemento esencial del régimen republicano de gobierno, se encuentra consagrada en su artículo cuarto el cual señala: Chile es una República democrática. Por lo tanto, la responsabilidad a la que en términos generales y sin ningún tipo de exclusión alude el artículo sexto es, sin lugar a dudas, jurídica en todas sus variantes, la cual incluye la responsabilidad patrimonial.

Lo anterior se ve reforzado pues en la actualidad, bajo el paradigma del Estado Constitucional de Derecho, la fuerza normativa directa de la Constitución, sin necesidad de la mediación de la ley, es indiscutida. Entre nosotros está claramente consignada en el artículo $6^{\circ}$ inciso $2^{\circ}$ de la Carta Fundamental, que establece lo que ha sido denominado el principio de eficacia directa de la Constitución, en virtud del cual sus disposiciones deben ser aplicadas por cualquier ente con facultades jurisdiccionales. ${ }^{58} \mathrm{~A}$ partir de ello puede sostenerse que ya no es posible que existan disposiciones programáticas en nuestro Código Político pues, aunque no haya sido dictada una ley ordenada por ella o que facilitaría la aplicación de sus normas, impera directamente la Constitución como norma jurídica.

$\mathrm{Al}$ igual que en Francia, en donde diversas sentencias han acogido la hipótesis de un Estado Legislador responsable patrimonialmente ${ }^{59}-\mathrm{y}$ según la teoría de

\footnotetext{
${ }^{58}$ De Отто (2008) p. 76.

${ }^{59}$ Fue en 1938, en el conocido Arret de la Fleurette en donde por primera vez el Consejo de Estado francés estimó procedente una indemnización a cargo del Estado para resarcir de los prejuicios producidos a un ciudadano por una ley de 1934 que disponía:

"Está prohibido fabricar, promover, poner en venta o vender, importar, exportar o traficar: 1. Bajo la denominación de crema seguida o no de un calificativo o bajo una denominación de fantasía cualquiera, un producto que presente el aspecto de la crema, destinado a los mismos usos, no proveniente en forma exclusiva de la leche, la agregación o adición de materias grasas distintas a ésta, especialmente prohibida" CALDERA (1982) p. 101. Fue en 1963 en el caso conocido como el Arret Boveró, en donde el Consejo de Estado reconoció de forma más amplia la responsabilidad patrimonial legislativa. Desplazó el centro de gravedad de la consideración de la responsabilidad del Estado como una modalidad de régimen especial de responsabilidad, a ser considerada como una responsabilidad pública de derecho común o responsabilité sans faute, al fundarse sobre el principio de igualdad ante las cargas públicas. Mantuvo la doctrina de que la producción de un daño por un acto normativo obliga, como regla general, a indemnizar, a salvo de que el legislador haya excluido expresamente tal derecho. CHECA (2004) p. 50.
} 
Duguit $^{60}$ - para el ordenamiento jurídico chileno, el Estado se encuentra sustancialmente determinado por el principio de servicialidad, su orientación al bien común y el deber de respetar y promover plenamente, los derechos y garantías que la Constitución establece.

Para cumplir con dichas tareas, el Estado dispone de un grupo considerable de potestades frente a las personas, las cuales han de someterse a los principios de legalidad objetiva y subjetiva que exige el pleno imperio de los Derechos Fundamentales y el respeto por la Dignidad Humana. Estos principios se encuentran asociados al principio general de responsabilidad del Estado que, al igual que en caso español -en donde múltiples sentencias han recogido la teoría en comento ${ }^{61}$ presenta una formulación genérica en el artículo No 6 y sendas consagraciones específicas en su faz patrimonial en el artículo 19 No 7 literal I, referida a la responsabilidad patrimonial del Estado Juez en materia penal y en el artículo 38 inciso segundo, referido a la responsabilidad patrimonial del Estado por actos de la administración, sin que dichas referencias específicas tengan la virtud de restringir únicamente a dichos supuestos el deber de reparación patrimonial del Estado frente a sus intervenciones ablatorias de derechos.

En efecto, dichas disposiciones en lugar de ser consideradas como las únicas fuentes de responsabilidad patrimonial del Estado Fisco por actos de poderes del Estado, han de ser dimensionadas como disposiciones que concretan, perfilan y disciplinan la procedencia y alcance de la responsabilidad por hechos del juzgador y administrador en los casos que tales disposiciones mencionan, pero sin que ello signifique en caso alguno la negación de otras formas de responsabilidad patrimonial del Estado. Así el artículo 19 No 7 letra I precisa que: la causal de procedencia de la acción en contra del Estado Juez será la existencia de una resolución injustificadamente errónea o arbitraria que haya sometido a proceso o privado de libertad a una persona, que tal declaración acerca del carácter de la sentencia es resorte de la Corte Suprema además del plazo para requerirla y que

\footnotetext{
${ }^{60}$ Una excelente relación de los argumentos del Decano bordolés puede encontrase en ZÚNIGA (2005).

${ }^{61}$ Muestra de aquellas sentencias se encontraría por ejemplo en las del Tribunal Supremo de 5 de marzo de 1993, 27 de junio de 1994 y 6 de julio de 1999, referidas a la indemnización a que se tenía derecho por la eliminación de los cupos de pesca exentos de derechos arancelarios derivado del Tratado de Adhesión de España a la Unión Europea o con las sentencias del Tribunal Supremo de 8 de octubre de 1998 y 9 de octubre de 1998, en las que también se accedió a la petición de indemnización solicitada por los perjuicios ocasionados por el hecho de haberse implantado un impuesto por la Ley del Parlamento de Canarias 5/1986, de 28 julio, del Impuesto Especial sobre Combustibles Derivados del Petróleo, que las empresas afectadas no pudieron repercutir en cuanto a los stocks que tenían en sus depósitos en el momento de aplicarse la nueva imposición, dado que los precios de venta al público eran fijados administrativamente y al rebajarlos resultaron inferiores a la suma del precio de compra y el nuevo impuesto autonómico.
} 
corresponde que en un juicio posterior seguido ante tribunales de primera instancia se determine el monto de la reparación por el daño moral y patrimonial. ${ }^{62}$ Mientras que el artículo 38 inciso segundo expresa que la administración del Estado, sus organismos y las municipalidades son responsables patrimonialmente por las lesiones que irroguen a los derechos de las personas, quienes, en aquel caso, tienen la facultad de reclamar dicha responsabilidad ante los tribunales que determine la ley. Todo ello sin perjuicio de la responsabilidad del funcionario que hubiere causado el daño. ${ }^{63}$

Vale entonces, también para el caso chileno, lo que sobre este punto anota Jiménez Lechuga: "si la propia Constitución se fundamenta a sí misma sobre una serie de valores superiores en función de los que quiere ser interpretada y aplicada, y dos de esos valores superiores son, precisamente, la justicia y la igualdad, sería ir gravemente contra su espíritu, aunque se respetara su letra, hacer prevalecer normas, interpretaciones o soluciones que contradijesen o menoscabaran la efectividad de aquellos valores. ${ }^{64}$

Tampoco es menester, entonces, que la responsabilidad patrimonial de alguna de las ramas del Estado sea objeto de desarrollo legislativo para hacerse concreta, pues la fuerza directa de la Constitución es incompatible con la idea de la ley pantalla. ${ }^{65}$

Por otra parte, el dogma de la infalibilidad y plenitud de la soberanía, o fetichismo de la ley, en el caso chileno, se encuentra plenamente superado. Sabido es que el ejercicio de la soberanía reconoce como límite el respeto por los derechos esenciales que emanan de la naturaleza humana, sin distinción, pero guardando especial relevancia en este caso los derechos a la igualdad ante la autoridad, la ley, los tributos y las cargas públicas y los principios de buena fe, confianza legítima

\footnotetext{
${ }^{62}$ Henríquez y NúNÉz (2007) p. 234.

${ }^{63}$ Ibídem p. 339.

${ }^{64}$ JimÉNEZ J. (1999) p. 69.

${ }^{65}$ La idea de la "ley pantalla", tan bien descrita por el profesor francés Louis Favoreu, también ha ido despareciendo. Según esa tesis, la ley era una forma de regulación imprescindible, de modo que la Constitución no podía aplicarse si no se dictaban las respectivas normas legales que debían concretar una determinada institución. Bajo el imperio de la Constitución de 1925, así ocurrió con la institución de las Asambleas Provinciales, con los Tribunales Contencioso-Administrativos y con la acción de indemnización por error judicial. A su turno, la tesis de la "ley pantalla" también influyó en que algunos importantes órganos del Estado, como la Contraloría General de la República, afirmara la juridicidad de disposiciones reglamentarias, en base a la ley que las amparaba, aunque ésta fuera derechamente contraria a la Constitución. PEÑA, Marisol, Inconstitucionalidad de la ley y responsabilidad del Estado Legislador, Exposición realizada el 24 de agosto de 2007 en el IX Seminario de Actualidad Jurídica Chilena organizado por el Centro de Estudiantes de la Escuela de Derecho de la Universidad de Valparaíso, inédita.
} 
y seguridad jurídica. Además conocido es, también, que la actividad legislativa se haya sujeta a un doble control de su adecuación a la Constitución. ${ }^{66}$

Por último, el carácter general de la ley, rasgo empleado en la jurisprudencia temprana de los tribunales franceses para negar la procedencia de la reparación patrimonial de los perjuicios eventualmente ocasionados por esta fuente del Derecho, tampoco constituye un argumento categórico para negar la responsabilidad del Estado Legislador, toda vez que éste descansa en la idea de que la única antijuridicidad posible sería la violación de la igualdad ante las cargas públicas mediante la imposición de un sacrificio especial a una persona determinada, lo cual no ocurriría si la ley afectase a todos por igual. Empero, como es sabido, en el Estado Constitucional de Derecho, la antijuridicidad de la ley puede provenir de la vulneración a cualquier disposición de la Carta Fundamental, sea que afecte esta en sus derechos constitucionales a un solo individuo o a todos por igual.

Por otra parte, es fácilmente constatable que en la actualidad la generalidad como característica esencial de la ley es una propiedad que brilla por su ausencia. En este sentido Francisco Laporta, refiriéndose a la crisis actual de concepto de ley, expresa que proliferan las leyes de caso único, las leyes ad hoc, las leyes -medida, las leyes fotografía, las leyes programa, las habilitaciones al gobierno, etc. Para usar una terminología que ha sido sugerida hace algún tiempo podemos estar pasando de un sistema de providencia general a uno de providencia especial, en el que los poderes pretender erigir una regulación particular para cada sujeto o grupo de sujetos, con todos los riesgos que ello comporta. ${ }^{67}$

\section{ReSPONSABILIDAD PATRIMONIAL DEL ESTADO LEGISLADOR COMO GARANTÍA JURISDICCIONAL DEL CONTRIBUYENTE, ALGUNOS EJEMPLOS}

Tres fueron fundamentalmente las decisiones que abrieron el camino para un reconocimiento amplio del deber del Estado de indemnizar los daños producidos por una ley declarada inconstitucional, incluso cuando la sentencia estimativa no tenga efecto retroactivo: la de 29 de febrero de 2000, y las de 13 de junio y 15 de julio del mismo año. A partir de ellas se concretó el reconocimiento de una acción jurisdiccional-reclamatoria de indemnización de perjuicios- que debe ser conocida por la magistratura competente según las reglas generales para resolver acciones

\footnotetext{
${ }^{66}$ Como escribió Bachof, si por siglos los derechos esenciales eran lo que la ley determinaba, aunque existiera ya una Constitución, ahora la ley es tal y vale sólo en la medida que regula el ejercicio de aquellos derechos, respetándolos en los términos proclamados y asegurados en la Carta Fundamental. De modo que, hasta hoy, al menos, el modelo weberiano de la dominación racional sobre la base de la legalidad formal va quedando superado. BACHOF (1983) p. 44.

${ }^{67}$ LAPORTA (2007) p. 159.
} 
patrimoniales en contra del Estado y que ha de tener como antecedente necesario la declaración de inconstitucionalidad de la norma legal que es causa directa del perjuicio alegado por el demandante. Tales daños deben ser antijurídicos en razón de su inconstitucionalidad. Justamente en los tres ejemplos que revisaremos, los litigantes son contribuyentes que abonaron sumas en arcas fiscales por concepto de tributos posteriormente declarados inconstitucionales. Lo cual nos respalda directamente en la tesis central de este trabajo.

En la primera de las referidas sentencias, se reconoció el derecho a indemnización de un contribuyente que había agotado todas las instancias de impugnación del cobro, en la segunda se extendió este derecho a un demandante que no había realizado dichas gestiones y en la tercera se sistematizó la doctrina ensayada en las resoluciones precedentes. De esta última destaca la siguiente conclusión del Tribunal Supremo:

En nuestro sistema legal, quienes han tenido que satisfacer el gravamen complementario, impuesto por el precepto declarado inconstitucional, después de haber impugnado en vía administrativa y sede jurisdiccional dicho gravamen obteniendo sentencia firme que lo declara conforme a derecho, no tienen otra alternativa, en virtud de lo dispuesto por el art. 40.1 de la Ley Orgánica 2/1979, del Tribunal Constitucional, que ejercitar, como en este caso ha procedido la entidad demandante, una acción por responsabilidad patrimonial, derivada del acto del legislador, dentro del plazo fijado por la ley.

Si no hubieran impugnado jurisdiccionalmente las liquidaciones de dicho gravamen complementario, los interesados tienen a su alcance la vía de pedir, en cualquier momento, la revisión de tal acto nulo de pleno derecho, como prevé el art. 102 de la LRJ-PAC, y, simultánea o sucesivamente, de no tener éxito dicha revisión, están legitimados para exigir responsabilidad patrimonial derivada de actos del legislador, pero también pueden utilizar directamente esta acción, ya que no cabe imponer a quien ha sufrido un daño antijurídico la vía previa de la revisión de disposiciones y actos nulos de pleno derecho, a fin de dejarlos sin efecto, y sólo subsidiariamente permitirle demandar la reparación o indemnización compensatoria por responsabilidad patrimonial, cuando son las propias Administraciones quienes deben proceder a declarar de oficio la nulidad de pleno derecho de tales disposiciones o actos y el ciudadano descansa en la confianza legitima de que la actuación de los poderes públicos se ajusta a la Constitución y a las leyes.

Por otra parte, en las mencionadas sentencias, se consolidó la tesis de la subordinación plena del legislador a la Constitución. Así, por ejemplo el fundamento de Derecho cuarto de la sentencia del Tribunal Supremo de 29 de febrero de 2000 es un claro ejemplo de defensa del valor normativo de la Constitución ante el legislador y de la categórica ilegitimidad en que se halla envuelta una norma de tal tipo que vulnere el programa normativo definido por la Carta Suprema. Así el referido considerando señala: 
La ley declarada inconstitucional encierra en sí misma, como consecuencia de la vinculación más fuerte con la Constitución, el mandato de reparar los daños y perjuicios concretos y singulares que su aplicación pueda haber originado (...) Existe una notable tendencia en la doctrina y en el derecho comparado a admitir que, declarada inconstitucional una ley, puede generar un pronunciamiento de reconocimiento de responsabilidad patrimonial cuando aquella ocasione, privación o lesión de bienes, derechos o intereses jurídicos protegibles. (...) el Poder Legislativo no está exento de sometimiento a la Constitución y sus actos -las leyes- quedan bajo el imperio de tal norma suprema. En los casos donde la ley vulnere la Constitución, evidentemente el Poder Legislativo habrá conculcado su obligación de sometimiento, y la antijuridicidad que ello supone traerá consigo la obligación de indemnizar.

La sentencia dictada por el mismo tribunal con fecha 13 de junio de 2000, también, repite de forma casi íntegra el fundamento jurídico previamente trascrito, empero, se ocupa además de destacar el carácter de hecho que ante la Constitución como norma, tiene la actividad del legislador, ello a través del concepto de imputabilidad construido en base a la declaración de inconstitucionalidad de la norma. Así, su fundamento de Derecho cuarto expresa que:

La determinación del título de imputación para justificar la responsabilidad del Estado Legislador por inmisiones legislativas en la esfera patrimonial (que ha vacilado entre las explicaciones que lo fundan en la expropiación, en el ilícito legislativo y en la teoría del sacrificio, respectivamente) ofrece asi una especial claridad en el supuesto de ley declarada inconstitucional.

Y, por su parte, la sentencia de 15 de julio de 2000, también dictada por la citada magistratura, ofrece un contundente e inapelable reparo a la defensa de la fuerza vinculante de una ley contraria a la Constitución. En efecto en su fundamento de Derecho primero, para concluir que las prestaciones impuestas por una norma declarada inválida no generan obligación alguna, sino, por el contrario, deben ser resarcidos los afectados, dispone:

No parece necesario abundar en razones explicativas de la antijuridicidad del daño causado por el desembolso de determinadas cantidades en concepto de gravamen complementario sobre la tasa de juego, pues tal abono se produjo exclusivamente en virtud de lo dispuesto por el artículo 38.2 de la ley 5/1990, de 29 de Junio, declarado inconstitucional por sentencia del Tribunal Constitucional 173/1996 de 31 de octubre, de manera que quienes lo efectuaron no tenian el deber de soportarlo.

\section{Conclusiones}

A raíz de lo expuesto en el presente trabajo, podemos concluir lo siguiente:

La figura de la responsabilidad patrimonial del Estado Legislador ha hecho irrupción recientemente en el Derecho Público. Sin perjuicio de las alusiones que 
a ella se hacen en la doctrina administrativista de fines del siglo XVIII y comienzos del siglo XX, el actualmente en curso ha sido testigo privilegiado de su progresiva consolidación.

El término garantía es uno de los más empleados por el lenguaje jurídico. En un sentido amplio, y distinguiéndolo debidamente de los objetos protegidos, podemos entender que con el concepto garantía se alude a los instrumentos o medios mediante los cuales el Derecho protege y tutela dicho bien o valor o más específicamente a las técnicas de tutela de los Derechos Fundamentales.

Las garantías de los Derechos Fundamentales pueden agruparse en tres niveles, uno correspondiente a su positivación, otro constituido por las garantías abstractas y un tercero referido a las garantías jurisdiccionales.

La Constitución chilena reviste al contribuyente de protección en estos tres ámbitos, constituyendo la principal garantía jurisdiccional la institución de la responsabilidad patrimonial del Estado Legislador.

La recepción y consolidación de la responsabilidad patrimonial del Estado Legislador, se ve favorecida por la existencia de un sistema de control abstracto de constitucionalidad con régimen de eficacia de los actos declarativos de invalidez sin efectos retroactivos, tal como el que el artículo 94 de la Constitución chilena atribuye a las sentencias que sobre la materia pronuncia el Tribunal Constitucional. De lo anterior da cuenta la experiencia española que nos demuestra que de la confluencia de sentencias estimatorias de inconstitucionalidad con efecto pro futuro, con un principio general de responsabilidad del Estado y en sistemas con una Constitución plenamente normativa, el resultado que se produce es el reconocimiento del deber reparatorio del Estado por los actos del legislador, contrarios a la Constitución, que afecten derechos de particulares.

La breve relación que hemos efectuado acerca del origen y justificación efecto pro futuro de las sentencias de inconstitucionalidad sirve para ilustrar la existencia de poderosas razones para que la jurisdicción constitucional opere aplicándolo y que normas positivas lo contemplen. Inclusive, el caso español, en donde tal efecto no resulta evidente a partir de la Ley Orgánica que disciplina el funcionamiento del Tribunal Constitucional, pero a fuerza de los hechos y las circunstancias dicho tribunal se ha visto en la necesidad de adoptarlo mediante una doctrina jurisprudencial, da fe de su utilidad para el Estado Constitucional de Derecho. Sin embargo, la disociación entre inconstitucionalidad y nulidad en las sentencias estimativas no debe hacernos olvidar la lógica basilar de un Estado en el que Constitución es la norma jurídica suprema.

Todo lo anterior, nos sirve para dar por confirmada la hipótesis central del presente trabajo, cual es que: en jurisdicciones que cuentan con sistemas de jus- 
ticia constitucional concentrados capaces de invalidar leyes vigentes mediante sentencias con efectos pro futuro, el contribuyente, en virtud del propio principio de supremacía constitucional y en atención al contenido de los derechos reconocidos por el propio sistema, goza de una garantía jurisdiccional de esos derechos constituida por la acción de responsabilidad patrimonial del Estado por actos del Legislador.

\section{Bibliografía}

Ahumada Ruiz, María (1991): "El control de constitucionalidad de las omisiones legislativas", en RCEC (No 8), pp. 169 -194.

AleXY, Robert (1993): Teoría de los derechos fundamentales. (Madrid, Centro de estudios políticos y constitucionales).

Aylwin Azócar, Patricio (1960): Derecho Administrativo, (Santiago, Editorial Universitaria).

BACHOF, Otto (1983): Jueces y Constitución (Madrid, Editorial Civitas).

Ballaguer Callejón, María Luisa (2001): El recurso de inconstitucionalidad. (Madrid, Centro de Estudios Políticos y Constitucionales).

Bielsa, Rafael (1938): Derecho administrativo (Buenos Aires, Depalma).

Bordalí Salamanca, Andrés, (2002): Temas de derecho procesal constitucional. (Santiago, Editorial Fallos del Mes).

Caldera Delgado, Hugo (1982): Sistema de responsabilidad extracontractual del Estado en la Constitución política de 1980 (Santiago, Editorial Jurídica).

Cea Egaña, José Luis (2003): Derecho Constitucional Chileno. (Santiago, Ediciones Universidad Católica de Chile) Tomo II.

CheCA GonzÁlez, Clemente (2004): "La responsabilidad patrimonial de la administración pública con fundamento en la declaración de inconstitucionalidad de una ley", en Revista Ius et Praxis, (Año 10, No 1), pp. 45 -75.

De Отто, Ignacio (2008): Derecho Constitucional, Sistema de Fuentes (Barcelona, Ariel).

Delaveau Swett, Rodrigo (2006): "La Regulación Expropiatoria en la Experiencia Norteamericana”, Revista Chilena de Derecho, (vol. 33 No 3), pp. 411-438.

Evans de la CuAdra, Enrique (1997): Los tributos ante la Constitución (Santiago, Editorial Jurídica de Chile).

Fermandois VÖHringer, Arturo (2005): “Inaplicabilidad de la ley de monumentos nacionales: hacia la inconstitucionalidad de la expropiación regulatoria en Chile", en A.A.V.V. Sentencias Destacadas 2004 (Santiago, Libertad y Desarrollo) pp. 19-55. 
FERnÁNdez RodríGUeZ, José Julio (2007): La Justicia constitucional europea ante el siglo XXI (Madrid, Tecnos).

FERNÁNDEZ, Miguel Ángel (2000): "Principios constitucionales de proporcionalidad y justicia en materia tributaria", en Revista Chilena de Derecho, (Vol. 27 No 2), pp. 357-371.

Ferrajoli, Luigi (2008): Garantías en CARBONELL, Miguel (Editor) Luigi Ferrajoli: Democracia y Garantísmo (Madrid, Trotta) pp. 27-41.

GarCía DE EnTERRÍA, Eduardo (2007): La responsabilidad patrimonial del Estado legislador en el derecho español (Madrid, Civitas).

García Mendoza, Hernán: Responsabilidad extracontractual del Estado (Santiago, Editorial Jurídica ConoSur).

GarCíA Morillo, Joaquín (1994): La protección judicial de los derechos fundamentales (Valencia, Tirant Lo Blanch).

GASCON, Marina (1997): "Sentido y alcance de algunas distinciones sobre la invalidez de las leyes", en Doxa (No 20), pp. 131-156.

Henríquez Viñas, Miriam y Núñez Leiva, José Ignacio (2007): Manual de estudio de Derecho Constitucional actualizado según la reforma de 2005 (Santiago. Editorial Metropolitana).

Huerta Ochoa, Carla (2001): "Artículos transitorios y derogación”, en Boletín Mexicano de Derecho Comparado, (No 102), pp. 811-840.

Jiménez CAmpo, Javier. (1999): Derechos Fundamentales. Concepto y garantías (Madrid, Trotta).

Jiménez Lechuga, Francisco (1999): La Responsabilidad Patrimonial de los Poderes Públicos en el Derecho Español. Una visión de conjunto (Madrid, Marcial Pons Ediciones Jurídicas y Sociales S.A.).

La Porta San Miguel, Francisco (2007): El imperio de la ley, una visión actual (Madrid, Trotta).

NúŃEz LeIVA, J. Ignacio (2008) "Antecedentes de la Responsabilidad Patrimonial del Estado Legislador y su aplicación al caso chileno”, en Revista de Derecho, Universidad Católica del Uruguay, (No 3), pp. 135-154.

Núñez LeIva, J. Ignacio (2009a) "Un análisis abstracto del Derecho Penal del Enemigo a partir del Constitucionalismo Garantista y Dignatario", en Revista Política Criminal, (No 8), pp. 1-23.

NúñEz Leiva, J. Ignacio (2009b) "Derecho Penal del Enemigo y Dignidad Humana en el Estado Constitucional de Derecho" en Memoria del X Congreso Iberoamericano de Derecho Constitucional (Lima, Idemsa) pp. 327-346. 
NúñEz Leiva, J. Ignacio (2009c): "Los límites al ejercicio de los Derechos Fundamentales en el Constitucionalismo de los Derechos" en Revista Estudios Jurídicos, Universidad Católica del Uruguay, (No 7), pp. 229-248.

Sastre Ariza, Santiago (2000): "Derecho y Garantías", en Revista Jueces para la democracia (No 38), pp. 47-55.

SCHÄFFER, Heinz (1998): Austria La relación entre el. Tribunal Constitucional y el legislador, en AJA, ELISEO (EDITOR) Las Tensiones entre el Tribunal Constitucional y el Legislador en Europa (Barcelona, Ariel) pp. 37-55.

Vedel, Georges (1980): Derecho Administrativo (Madrid, Aguilar).

Zagrebelsky, Gustavo (2008): Principios y votos. El tribunal constitucional y la política (Madrid, Trotta).

Zavala Ortiz, José Luis (2009): Manual de Derecho Tributario (Santiago, Thomson Reuters).

Zúñiga Urbina, Francisco (2005): Responsabilidad Patrimonial del Estado Legislador (Santiago, LexisNexis). 